\title{
Modelling the evolution of supraglacial lakes on the West Greenland ice-sheet margin
}

\author{
M. LÜTHJE ${ }^{1}$, L.T. PEDERSEN ${ }^{1}$, N. REEH ${ }^{1}$, W. GREUELL ${ }^{2}$ \\ ${ }^{1}$ Ørsted DTU, Electromagnetic Systems, Technical University of Denmark, Building 348, Ørsteds Plads, \\ DK-2800 Kgs. Lyngby, Denmark \\ E-mail: mikael@lythje.com \\ ${ }^{2}$ Institute for Marine and Atmospheric Research, Utrecht University, 3508 TA Utrecht, The Netherlands
}

\begin{abstract}
We present a model study investigating the summer evolution of supraglacial lakes on the Greenland ice margin. Using a one-dimensional (1-D) model we calculate the surface ablation for a bare ice surface and beneath supraglacial lakes for 30 days in the summers of 1999 and 2001. The surface ablation beneath the lake was enhanced by $110 \%$ in 1999 and $170 \%$ in 2001 compared with the ablation for bare ice. We then use the results from the 1-D model to further model the vertical and horizontal evolution of the supraglacial lakes, the results of which are compared with satellite images. Within the region of the ice sheet where supraglacial lakes presently occur, the area covered by supraglacial lakes is found to be more or less independent of the summer melt rate but controlled by topography. We therefore predict that, inside this region, the area covered by supraglacial lakes will remain constant even in a warmer climate. However, in a warmer climate, surface melting will occur higher on the ice sheet where small surface slopes favour formation of large supraglacial lakes. Enhanced surface melting beneath such lakes is a hitherto overlooked feedback mechanism related to climate warming.
\end{abstract}

\section{INTRODUCTION}

Ablation on the Greenland ice sheet is largely controlled by net shortwave radiation (Greuell and Knap, 2000), and therefore variations in the surface albedo are very important. In the ablation area of the Greenland ice sheet, supraglacial lakes form during summertime. The lakes appear as 'dark' spots of low albedo on the ice sheet of much higher albedo. On Arctic sea ice Perovich and others (2002) found that the presence of melt ponds can lower the overall summertime sea-ice albedo from 0.65 to 0.4 , and suggested that increased surface melting of sea ice will lead to greater melt-pond coverage, thus decreasing the area average albedo, and further enhance melting (Morassutti, 1992; Perovich and Tucker, 1997).

Supraglacial lakes have been studied on the Greenland ice sheet (e.g. Thomsen and Reeh, 1986; Echelmeyer and others, 1991), on Svalbard (Liestøl and others, 1980) and on glaciers in the Himalaya (Ageta and others, 2000; Benn and others, 2000; Reynolds, 2000). Lake locations were mapped in a limited area of the West Greenland ice margin (Thomsen, 1986; Thomsen and others, 1988). Comparing the position in different years, the lakes were found in the same locations (Thomsen and others, 1988; Echelmeyer and others, 1991; Jezek and others, 1993; Lüthje, 2005). More recently, a study has measured the albedo of different surface types of the ice sheet, including the albedo of supraglacial lakes (Greuell and others, 2002). However, the contribution of supraglacial lakes to enhanced ice-sheet ablation remains unstudied. This subject is addressed by the present study, in which we present a melt model that quantifies the difference between the ablation for a bare ice surface and the ablation beneath a supraglacial lake. The model is forced with climatic data measured on the Greenland ice sheet in two different years where the total surface ablation in July differed by $40 \%$. The output from the model is used as input to a drainage model describing the vertical and horizontal evolution of supraglacial lakes in a limited area, situated around $67^{\circ} 20^{\prime} \mathrm{N}, 48^{\circ} 57^{\prime} \mathrm{W}$ (Fig. 1). Finally, we compare the result from the drainage model to the observed area coverage of supraglacial lakes as derived from moderate-resolution imaging spectroradiometer (MODIS) and Landsat 7 satellite images.

\section{ICE-MELT MODEL}

A convenient way of solving a system with phase changes (Stefan problems) is to use the enthalpy method (Alexiades and Solomon, 1993). Since enthalpy is defined as the total energy of the system, there is no need for tracking the phase boundary as it is a natural part of the solution. The basic structure of the melt model is the same for the case of a bare ice surface and an ice surface beneath a lake, with only small differences (commented on later). If the enthalpy is zero for a volume of ice at its melting point, $T_{\mathrm{m}}=0^{\circ} \mathrm{C}$, then the change in enthalpy, $E$, for a volume of ice at a lower temperature, $T$, is:

$$
E=\left(T-T_{\mathrm{m}}\right) \times(\rho c)_{\mathrm{s}^{\prime}}, \quad T<T_{\mathrm{m}}
$$

where $(\rho c)_{\mathrm{s}}$ is the volumetric heat capacity of ice. In this case the liquid fraction, $\lambda$, is zero. For a temperature greater than $T_{\mathrm{m}}$ the change in enthalpy of the melted ice volume is instead given by:

$$
E=\rho L+\left(T-T_{\mathrm{m}}\right) \times(\rho c)_{1}, \quad T>T_{\mathrm{m}},
$$

where $(\rho c)_{\mid}$is the volumetric heat capacity of water and $L=3.348 \times 10^{5} \mathrm{~J} \mathrm{~kg}^{-1}$ is the latent heat of fusion. The liquid fraction, $\lambda$, is then 1 .

If the temperature is at the melting point then $0<E<\rho L$ and $\lambda=E / \rho L$. The volume of ice down to a depth $L_{z}$ is divided into $N$ control volumes, each of height $\Delta z=L_{z} / N$ and with a volume of $\Delta z \times A$, where $A$ is the area of the control volume. $N$ is fixed throughout, whereas $L_{z}$, and therefore $\Delta z$, can be varied. All control volumes are 
initialized with an enthalpy corresponding to a temperature profile with a depth gradient of $2 \mathrm{~K} \mathrm{~m}^{-1}$. This assumption is based on measurements from Pâkitsoq, West Greenland (personal communication from O. Olesen and H.H. Thomsen). Since the drainage model is developed for a snow-free surface only, the calculation begins when the snow has disappeared (see section 2.3.1).

\subsection{Conductive heat transport through ice}

Energy transport, $q$, within the ice is assumed conductive and given by (Alexiades and Solomon, 1993):

$$
q_{j-\frac{1}{2}}=\frac{T_{j}-T_{j-1}}{\frac{\frac{1}{2} \Delta z_{j-1}}{k_{j-1}}+\frac{\frac{1}{2} \Delta z_{j}}{k_{j}}},
$$

where $j=1, \ldots, N$ is the 'position' of the volume element and $k_{j}$ is the effective conductivity and is assumed to be the sum of the conductivities of the different phases:

$$
k_{j}=\lambda_{j} k_{\mathrm{l}}+\left(1-\lambda_{j}\right) k_{\mathrm{s}}
$$

where $k_{\mathrm{l}}=0.569 \mathrm{~W} \mathrm{~m}^{-1} \mathrm{~K}^{-1}$ is the conductivity in the liquid state and $k_{\mathrm{s}}=1.88 \mathrm{~W} \mathrm{~m}^{-1} \mathrm{~K}^{-1}$ is the conductivity in the solid state (Incropera and DeWitt, 2002).

Since melting takes place in the surface layer and enthalpy variations only occur in the uppermost part of the ice sheet, only the top $4 \mathrm{~m}$ of the ice were modelled. An initial grid size of $1 \mathrm{~cm}$ was used. At the bottom boundary, Neumann conditions were applied, i.e. no heat flux across the boundary.

\subsection{Turbulent heat transfer through lake water}

Since fresh water has its maximum density at $4{ }^{\circ} \mathrm{C}$, water that is heated from $0^{\circ} \mathrm{C}$ at the surface will be denser than the water at the bottom of the lake. Taylor and Feltham (2004) found that even for small melt ponds on Arctic sea ice, very small temperature differences between top and bottom resulted in turbulence. The heat flux between the turbulent lake and the ice bottom can be calculated using the 'four thirds' law (Linden, 2000):

$$
F=r \rho_{\text {water }} C_{l}\left(\beta g \kappa_{l}^{2} \nu^{-1}\right)^{1 / 3} \Delta T^{4 / 3} .
$$

$r$ is a dimensionless constant set to be 0.1 (Huppert, 2000; Taylor and Feltham, 2004), $\rho_{\text {water }}=1000 \mathrm{~kg} \mathrm{~m}^{-3}$ is the density of water, $c_{l}=4217 \mathrm{~J} \mathrm{~kg}^{-1} \mathrm{~K}^{-1}$ is the specific heat capacity (Incropera and DeWitt, 2002), $\beta=6.8 \times 10^{-5} \mathrm{~K}^{-1}$ is the coefficient of thermal expansion, $\kappa_{\mathrm{l}}=k_{\mathrm{l}} / \rho_{\text {water }} C_{\mathrm{l}}$ is the thermal diffusivity, $v=1.75 \times 10^{-6} \mathrm{~m}^{2} \mathrm{~s}^{-1}$ is the kinematic viscosity (Incropera and DeWitt, 2002), and $\Delta T$ is the temperature difference between the core temperature of the lake and the boundary temperature. A turbulent mixed water column is expected to have an interior (core) of a constant temperature, and the entire temperature difference is found at the boundaries (Linden, 2000). Thomsen and Reeh (1986) reported uniform temperature depth profiles in West Greenland supraglacial lakes with depths varying from 1.2 to $4.2 \mathrm{~m}$, indicating turbulent heat transfer. In August 2003, this finding was confirmed by temperature measurements in two supraglacial lakes within the ice margin sector described in the present study; no difference in temperature with depth was observed. To achieve this in the model, the mean temperature for the lake is found by taking the average of the temperature in the lake, and all interior gridcells with a liquid fraction of 1 are then assigned this temperature.

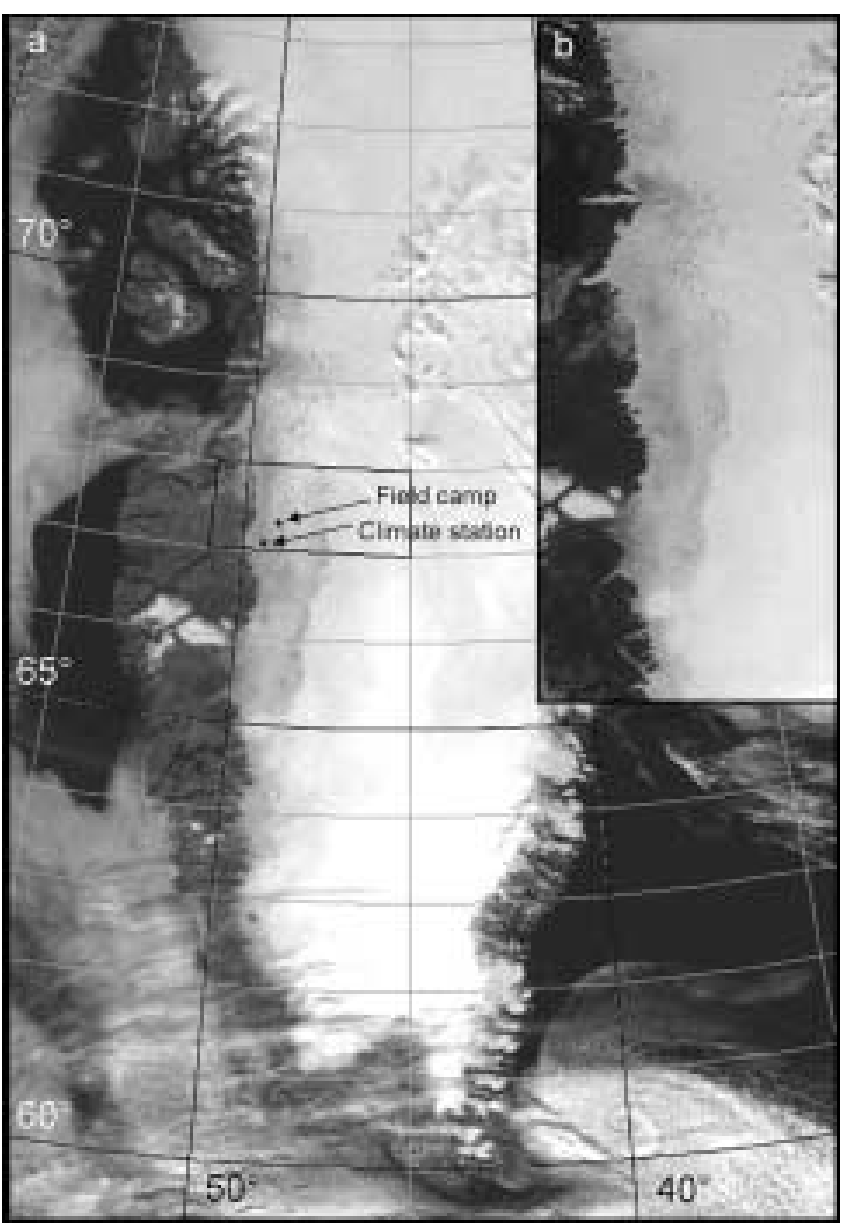

Fig. 1. MODIS image taken on 26 August 2000 showing most of Greenland, with a resolution of (a) 1000 and (b) $250 \mathrm{~m}$. (a) The arrows mark the positions of the field camp occupied in August 2003 and the climate station. (b) The area investigated for aerial coverage of supraglacial lakes.

\subsection{Surface boundary condition}

The melt model is forced by the net incoming energy flux at the interface between ice and atmosphere given by

$$
F_{\text {net }}=\left(1-I_{0}\right)(1-\alpha) F_{\text {sw }}+F_{\text {lw }}+F_{\text {sen }}+F_{\text {lat }}-F_{\text {lw_out }} .
$$

$F_{\mathrm{sw}}$ and $F_{\mathrm{Iw}}$ are the measured shortwave and longwave incoming radiant fluxes. $F_{\text {sen }}$ and $F_{\text {lat }}$ are sensible and latent heat fluxes, respectively, and $F_{\text {lw_out }}$ is outgoing longwave radiant flux. $\alpha$ is surface albedo. The parameter $I_{0}$ represents the fraction of shortwave radiation that is not absorbed at the surface but heats deeper layers of the ice-water column.

The sensible and latent heat fluxes were calculated using a bulk method where the fluxes are proportional to the difference in temperature and vapour pressure (Oerlemans, 1992; Zuo and Oerlemans, 1996).

$$
\begin{aligned}
F_{\text {sen }} & =C\left(T_{\text {air }}-T_{\mathrm{s}}\right) \\
F_{\text {lat }} & =\frac{0.622 L_{\mathrm{v}}}{C_{\text {air }} p} C\left(e_{\text {air }}-e_{\text {sat }}\left(T_{\mathrm{s}}\right)\right),
\end{aligned}
$$

where $C\left(\mathrm{~W} \mathrm{~m}^{-2} \mathrm{~K}^{-1}\right)$ is an exchange coefficient that, on average, accounts for the effect of variable wind speed and atmospheric stability, $T_{\text {air }}$ is air temperature $(\mathrm{K})$ at some reference level, $T_{\mathrm{s}}$ is ice surface temperature $(\mathrm{K})$, $L_{v}=2.501 \times 10^{6} \mathrm{~J} \mathrm{~kg}^{-1}$ is the latent heat of vaporisation, $C_{\text {air }}$ is the specific heat capacity of air $\left(1.005 \times 10^{3} \mathrm{~J} \mathrm{~kg}^{-1} \mathrm{~K}^{-1}\right)$, 


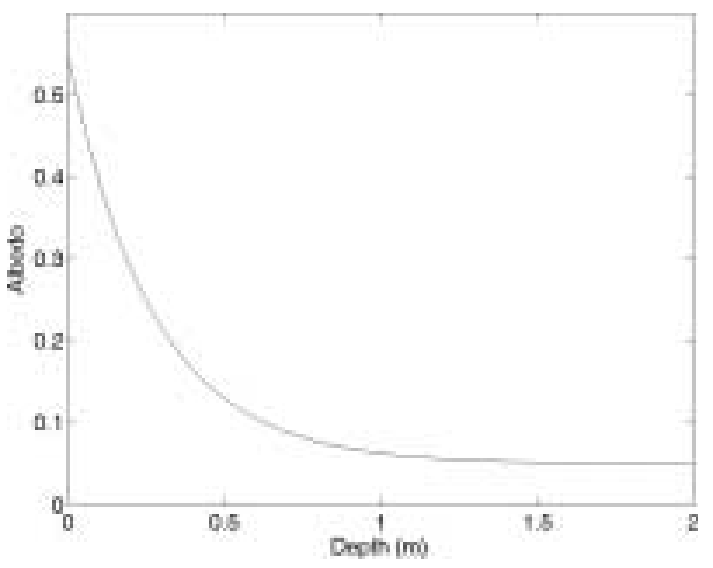

Fig. 2. Albedo vs lake depth based on the method presented by Taylor and Feltham (2004), using a bare-ice albedo of 0.55 .

$p$ is the atmospheric pressure $(\mathrm{Pa}), e_{\mathrm{sat}}$ is the saturation vapour pressure and $e_{\text {air }}$ is the vapour pressure $(\mathrm{Pa})$ at some reference level.

The outgoing longwave radiation is calculated as $\varepsilon \sigma T_{\mathrm{s}}^{4}$, where $\varepsilon$ is surface emissivity and $\sigma=5.67 \times 10^{-8} \mathrm{~W} \mathrm{~m}^{-2} \mathrm{~K}^{-4}$ is the Stefan-Boltzmann constant.

\subsubsection{Albedo and transmitted fraction $I_{0}$ of shortwave radiation}

For the bare ice surface, the albedo was calculated from observed values of incoming shortwave radiation $F_{\mathrm{sw}}$ in and reflected shortwave radiation $F_{\text {sw_out }}$ (see section 3 ):

$$
\alpha=\frac{F_{\text {sw_out }}}{F_{\text {sw_in }}} .
$$

As the model is developed for a snow-free surface, the calculated surface albedo was also used to estimate the date when the snow cover had melted. When the albedo dropped below 0.6 we assumed that the snow layer had disappeared. In 1999 and 2001, this happened on 3 July at the latest. We ran the model for 30 days starting at this date. No refreezing of meltwater occurred in the model periods.

Unfortunately, few measurements of albedo vs depth of supraglacial lakes are reported in the literature. We are only aware of the measurements of Box (1997) from a West Greenland ice margin location at $650 \mathrm{~m}$ elevation. Measured albedo ranged from 0.23 , with pond depth less than $1 \mathrm{~cm}$, to 0.15 when pond depth was $106 \mathrm{~cm}$.

On the other hand, measurements of the albedo-depth relationship for melt ponds on Arctic sea ice are abundant (Morassutti and LeDrew, 1996; Hanesiak and others, 2001). Ebert and Curry (1993) used data from the Arctic Ocean sea ice published by Grenfell and Maykut (1977) and Grenfell and Perovich (1984) to parameterize pond albedo vs depth for four spectral bands. Morassutti and LeDrew (1996) also estimated a relationship between albedo and depth of melt ponds, based on a much larger dataset. The two parameterizations differ most at visible wavelengths. Ebert and Curry (1993) found a generally lower albedo that was a function of depth until around $70 \mathrm{~cm}$. Morassutti and LeDrew (1996) found that the albedo was independent of depth for depths greater than approximately $20 \mathrm{~cm}$. Taylor and Feltham (2004) took a different approach by using a two-stream model to get an approximation for the albedo vs depth. Using the method of Taylor and Feltham (2004), although with a lower albedo for bare ice $(0.55$ instead of 0.65$)$ to account for the generally lower albedo of glacier ice compared with that of sea ice, the following expression for the albedo of a supraglacial lake as a function of the depth of the lake $h$ is obtained:

$$
\alpha=\frac{9702+1000 \mathrm{e}^{3.6 h}}{-539+20000 \mathrm{e}^{3.6 h}} .
$$

This albedo-depth variation is shown in Figure 2. Compared with the few measurements by Box (1997), Equation (10) gives higher albedo values for $h<0.35 \mathrm{~m}$, and lower values for $h>0.35 \mathrm{~m}$. The maximum difference between the observations of Box (1997) and Equation (10) is 0.07 for $h=0.9 \mathrm{~m}$. The difference decreases rapidly with increasing depth. Although one may argue that melt ponds on sea ice typically have lower albedo than supraglacial lakes, we shall use the albedo-depth relationship given by Equation (10), realizing that the magnitude of our modelled melt rates beneath supraglacial lakes may then be overestimated. This point is commented on further in section 6 .

The parameter $I_{0}$ represents the fraction of shortwave radiation that is not absorbed at the surface but heats deeper layers of the ice-water column. In accordance with common practice, we assume that all solar energy is absorbed at a bare ice surface, rather than penetrating into the subsurface. Actually, choosing $I_{0}=0$ is necessary to make calculated melt rates match observations.

In the case of the supraglacial lake, a value of $I_{0} \neq 0$ is used. According to Perovich and others (1999), nearly all shortwave radiation above $700 \mathrm{~nm}$ is absorbed effectively at the water surface, whereas Grenfell (1979) found the fraction of incident shortwave radiation above $700 \mathrm{~nm}$ to be $40 \%$. In accordance with the latter result, we use $I_{0}=0.6$. The part of the radiation not reflected or absorbed at the lake surface is attenuated through the lake according to Beer's law (Ebert and Curry, 1993):

$$
F(z)=I_{0}(1-\alpha) F_{\mathrm{sw}} \mathrm{e}^{-\tau z},
$$

where $z$ is the depth below the lake surface, and $\tau=0.025 \mathrm{~m}^{-1}$ (Taylor and Feltham, 2004).

\subsubsection{Elevation variation of radiant fluxes}

The data used as input to the surface boundary condition of the melt model were collected on the West Greenland ice margin $\left(67^{\circ} 5^{\prime} \mathrm{N}, 49^{\circ} 23^{\prime} \mathrm{W}\right.$; Fig. 1$)$ at an elevation of $1000 \mathrm{~m}$. In order to estimate the melt rate at other elevations and locations, we need to assess the elevation gradient of various parameters. The shortwave incoming radiant flux is assumed to be independent of elevation (within the range 1000$1400 \mathrm{~m}$ ). To find the change with altitude an approximation of the longwave incoming radiation is used (Konzelmann and others, 1994):

$$
F_{\mathrm{lw} \_ \text {in }}=\left[\varepsilon_{\mathrm{CS}}\left(1-n^{p}\right)+\varepsilon_{\mathrm{oc}} n^{p}\right] \sigma T_{\mathrm{air}}^{4}
$$

where $\varepsilon_{\mathrm{cS}}$ is the clear-sky emissivity, $n$ the cloudiness $(0 \rightarrow 1)$, $p=4$ is a constant and $\varepsilon_{\mathrm{OC}}=0.952$ is the emissivity of an overcast sky. $\varepsilon_{\mathrm{CS}}$ was approximated by Konzelmann and others (1994) as:

$$
\varepsilon_{\mathrm{cs}}=0.23+b\left(\frac{e_{\text {air }}}{T_{\text {air }}}\right)^{1 / m}
$$

with $e_{\text {air }}$ in Pa and $T_{\text {air }}$ in K. $b=0.484$ and $m=8$ are constants. For the cloudiness we used $n=0.6$. The choice of this value is arbitrary, but lies within the range of values 
(0.51-0.67) suggested for nearby ice-margin sites by Konzelmann and others (1994), Van de Wal and Oerlemans (1994) and Zuo and Oerlemans (1996).

Using this approximation (Equation (12)), the longwave incoming radiation at 1000,1200 and $1400 \mathrm{~m}$ is calculated. The decrease with altitude is found and the result subtracted from the measured longwave incoming radiation to give an estimate of the incoming longwave radiation at other elevations.

The outgoing longwave radiation was calculated assuming an emissivity, $\varepsilon$, for bare ice of 0.99 and an emissivity for supraglacial lake surfaces of 0.97 , i.e. similar to the values for sea ice and melt ponds, respectively (Ebert and Curry, 1993).

\subsubsection{Sensible and latent heat fluxes}

For the exchange coefficient, $C$, used to calculate the sensible and latent heat fluxes (see Equations (7) and (8)), Oerlemans (1992) used a constant value of $8 \mathrm{~W} \mathrm{~m}^{-2} \mathrm{~K}^{-1}$. Zuo and Oerlemans (1996) used a value for $C$ that decreased exponentially with elevation. For elevations of 1400 and $1000 \mathrm{~m}, C$ was calculated as 3.3 and $5 \mathrm{~W} \mathrm{~m}^{-2} \mathrm{~K}^{-1}$, respectively. Ahlstrøm (2003) used somewhat higher values of 8 and $10 \mathrm{~W} \mathrm{~m}^{-2} \mathrm{~K}^{-1}$. For the present work, both 8 and $10 \mathrm{~W} \mathrm{~m}^{-2} \mathrm{~K}^{-1}$ were tested, but $8 \mathrm{~W} \mathrm{~m}^{-2} \mathrm{~K}^{-1}$ was chosen for all calculations because it gave the best fit to observed melt rates.

The reference vapour pressure, $e_{\text {air, }}$ appearing in Equations (8) and (13) is calculated as $e_{\text {air }}=e_{\text {sat }}\left(\mathrm{T}_{\text {air }}\right) \times q_{\mathrm{rh}}$, where $q_{\mathrm{rh}}$ is the relative air humidity assumed independent of elevation. Lacking measurements of $q_{\mathrm{rh}}$, we use the mean value $q_{\mathrm{rh}}=0.86$ measured for a 30 day period in July 2002 .

The saturation vapour pressure $e_{\text {sat }}$ over ice and water needed to estimate the latent heat flux (see Equation (8)) is calculated from approximations suggested by Kraus (1972):

and

$$
e_{\text {sat }}(\text { ice })=610.8 \exp \left[22.47\left(1-\frac{273.15}{T_{\text {air }}}\right)\right]
$$

$$
e_{\text {sat }}(\text { water })=610.8 \exp \left[19.858\left(1-\frac{273.15}{T_{\text {air }}}\right)\right] \text {. }
$$

Temperature and pressure are parameters that have a strong variation with elevation. We use a summer temperature lapse rate of $0.5 \mathrm{~K}(100 \mathrm{~m})^{-1}$ (Steffen and Box, 2001), and a pressure gradient of $10 \mathrm{~Pa} \mathrm{~m}^{-1}$ following an approximation suggested by Ahlstrøm (2003).

\section{DRAINAGE MODEL}

The drainage model is a modified version of the twodimensional model presented by Lüthje and others (2006) to calculate the area covered by supraglacial lakes, using the calculated melt rates from section 2 as forcing. The elevation of the ice surface at position $i, j$ at time $t$ is denoted by $H$. The depth of a possible layer of meltwater is given by $h$ so the surface topography of the water-covered ice surface is:

$$
\Psi=h+H .
$$

The initial surface topography $\Psi_{i, j}^{0}$ comes from a digital elevation model (DEM) and is explained in more detail in section 4. The principle of mass conservation applied to the meltwater layer yields (Lüthje and others, 2006)

$$
\frac{\partial h}{\partial t}=\operatorname{He}(h)\left(\frac{\rho_{\text {ice }} \times m}{\rho_{\text {water }}}-\nabla \times(h \boldsymbol{u})\right) .
$$

$\mathrm{He}(h)$ is the Heaviside function preventing $h$ from becoming negative. For $h \geq 0, \mathrm{He}(h)=1$, otherwise $\mathrm{He}(h)=0$. $m$ is melt rate calculated as explained in section 2 . $\rho_{\text {ice }}=900 \mathrm{~kg} \mathrm{~m}^{-3}$ is ice density. $\boldsymbol{u}=(u, v)$ is defined as the horizontal flux vector (the depth-averaged flow velocity in the layer of meltwater) with components $u$ and $v$ along the $x$ and $y$ axis, respectively. $\nabla \equiv(\partial / \partial x, \partial / \partial y)$ is the horizontal gradient vector.

Water is transported to areas of lower gravitational potential by percolation through porous ice or snow, by supraglacial run-off in small streams and large rivers up to several metres in width (Fig. 3), and by subglacial run-off via moulins. We refrain from attempting to model this extremely complicated run-off pattern, the more so as the surface elevation DEM cannot resolve the streams and rivers. Instead, we make the simplest possible assumption, that $\boldsymbol{u}$ is proportional to the gradient of the surface topography:

$$
\boldsymbol{u}=\Omega \times \nabla \Psi,
$$

where $\Omega\left(\mathrm{m} \mathrm{s}^{-1}\right)$ is a tuning parameter representing the change in run-off with change in slope. Equation (17) can now be written as:

$$
\frac{\partial h}{\partial t}=\operatorname{He}(h)\left(\frac{\rho_{\text {ice }} m}{\rho_{\text {water }}}-\Omega \times \nabla \times(h \nabla \Psi)\right) .
$$

The evolution of ice surface elevation is given by (Lüthje and others, 2006):

$$
\frac{\partial H}{\partial t}=\frac{\partial \Psi}{\partial t}-\frac{\partial h}{\partial t}=-m .
$$

Equations (19) and (20) were discretized using finite differences, and the resulting algebraic equations were solved numerically. The maximum time-step used was $5 \mathrm{~s}$. Meltwater that reaches the downslope boundary disappears (run-off), whereas closed boundaries are applied to the other three sides of the model.

\section{DATA}

\subsection{Input data for melt model}

The data used as forcing for the melt model are shortwave incoming radiation, shortwave outgoing radiation, longwave incoming radiation, air temperature and atmospheric pressure. The data were collected on the West Greenland ice margin $\left(67^{\circ} 5^{\prime} \mathrm{N}, 49^{\circ} 23^{\prime} \mathrm{W}\right.$; Fig. 1) at an altitude of $1000 \mathrm{~m}$. Temperature, pressure, shortwave and longwave incoming radiation for 1999 and 2001 are displayed in Figure 4a and $b$, respectively.

\subsection{Input data for the drainage model}

The surface DEM used as initial condition for the drainage model was produced from synthetic aperture radar (SAR) data from 1995 (personal communication from J. Mohr). The horizontal resolution is $100 \mathrm{~m} \times 100 \mathrm{~m}$ and the relative vertical accuracy is of the order of $0.5 \mathrm{~m}$. One can therefore expect that the DEM will display artificial surface irregularities with amplitudes of the order of $0.5 \mathrm{~m}$. The model will accumulate water in the resulting artificially created depressions. Because of the relatively large surface slope (0.009) of the area studied, real lakes with depths less than $0.5 \mathrm{~m}$ do not occur. To minimize the effect of artificially created surface irregularities we therefore assume that lakes are not formed as long as the water depth is less than $0.5 \mathrm{~m}$. 


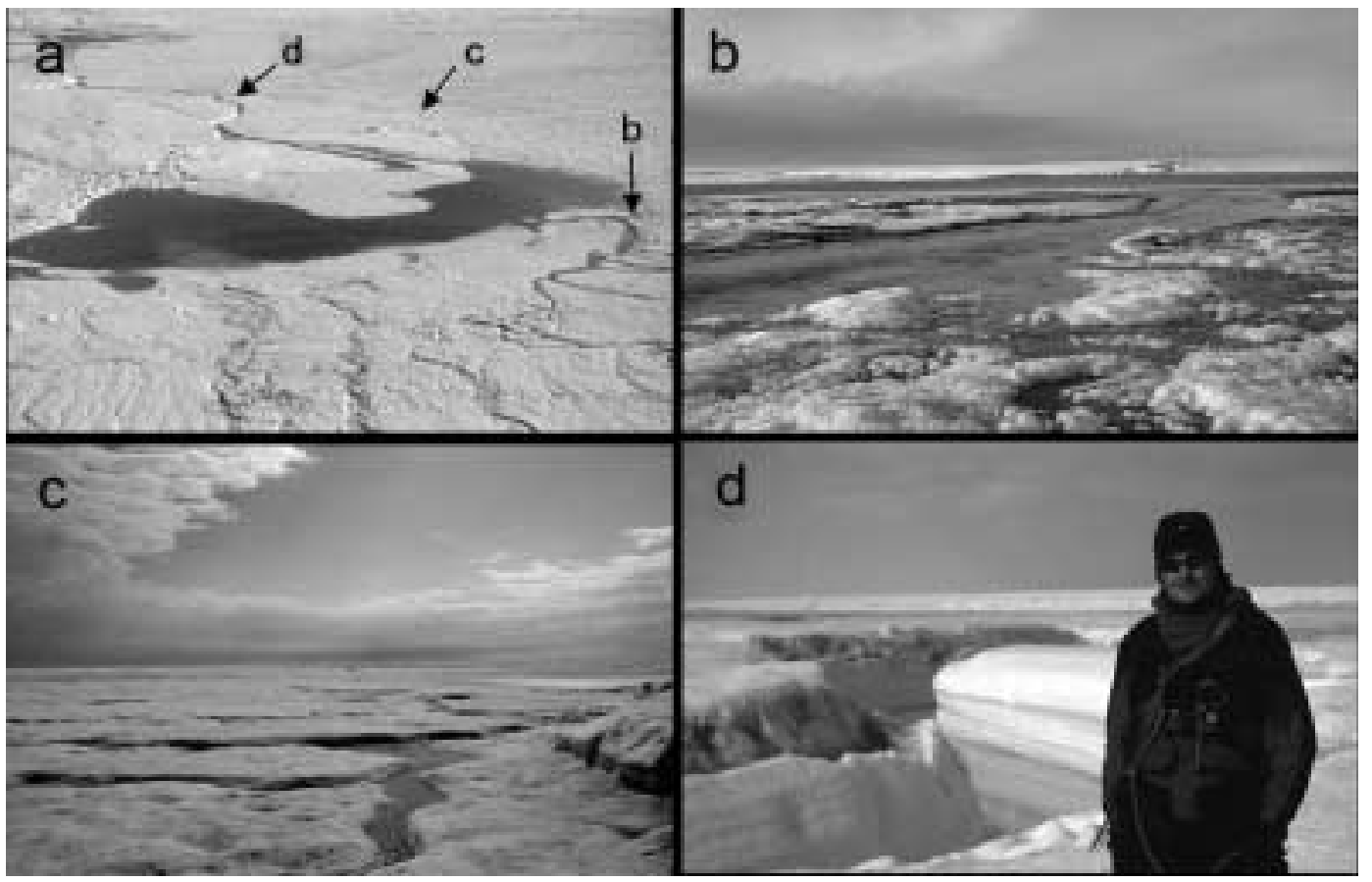

Fig. 3. Photographs from the field site on the Greenland ice sheet occupied in August 2003. (a) A supraglacial lake at $67^{\circ} 20^{\prime} \mathrm{N}, 48^{\circ} 57^{\prime} \mathrm{W}$ at an altitude of $1240 \mathrm{~m}$. The approximate locations of sites shown in (b-d) are marked. The distance between locations shown in (b) and (d) is around $1000 \mathrm{~m}$. (b) Water entered the lake by the river with an estimated velocity of $3-5 \mathrm{~m} \mathrm{~s}^{-1}$ and width $>2 \mathrm{~m}$. (c) A small river $(<0.5 \mathrm{~m}$ wide) of the type typically found all around the lake. (d) The outlet river that was much deeper and also broader (approximate width $>5 \mathrm{~m}$ ) than the inlet river. Water here flowed at a much lower velocity.

The SAR images used to produce the surface DEM are from the fall or winter, when the supraglacial lakes are frozen over. We assume that the lakes are frozen solid during the winter and, therefore, that large subsurface water pockets do not exist at the lake formation sites at the start of the subsequent melt season. This means that the frozen lakes are assumed to be included in the surface ice layer when the melting begins.

The drainage model was applied to a $20 \mathrm{~km} \times 20 \mathrm{~km}$ area located around a lake at $67^{\circ} 20^{\prime} \mathrm{N}, 48^{\circ} 57^{\prime} \mathrm{W}$ (Figs 1 and 3) where fieldwork was carried out in 2003. The area was divided into gridcells of $100 \mathrm{~m} \times 100 \mathrm{~m}$. Using the melt model, daily melt rates at 1000, 1200 and 1400 m elevation were calculated for a bare ice surface and beneath a supraglacial lake (with an initial depth of $50 \mathrm{~cm}$ ). Based on these results, daily melt rates were calculated by linear interpolation for each gridcell and used as input to the drainage model. The tuning parameter in Equation (18) was set to $\Omega=500 \mathrm{~m} \mathrm{~s}^{-1}$, but other values of $\Omega(1,10,100$, $250 \mathrm{~m} \mathrm{~s}^{-1}$ ) were also tested.

Table 1. Accumulated surface ablation after 30 days of melting for a bare ice surface at three different elevations in 1999 and 2001

\begin{tabular}{lcc}
\hline Elevation & 1999 & 2001 \\
$\mathrm{~m}$ & $\mathrm{~cm}$ & $\mathrm{~cm}$ \\
\hline 1000 & 87.0 & 61.8 \\
1200 & 79.1 & 54.1 \\
1400 & 70.1 & 47.1 \\
\hline
\end{tabular}

\section{RESULTS AND DISCUSSION}

\subsection{Melt model}

Table 1 shows the model-simulated total surface ablation after 30 days of melting in 1999 and 2001 for a bare, welldrained ice surface at three different elevations. Much higher surface ablation was found in 1999 than in 2001. In Figure $5 \mathrm{a}$ and $\mathrm{b}$ the modelled surface ablation at $1000 \mathrm{~m}$ elevation in 1999 and 2001, respectively, is compared with the observed surface ablation. The observed melt rate is more variable than the modelled melt rate, and is even negative (accumulation) for a few days. Most likely the discrepancies are due to the fact that the model does not consider precipitation either as snow or as rain. However, the overall correspondence between model and observation for the 30 day model period is excellent. As the model also captures the large observed difference between the amount of melting in 1999 and 2001, we are fairly confident of the validity of the model.

Table 2 shows the model-simulated total ablation after 30 days of melting for an ice surface at $1000 \mathrm{~m}$ elevation if meltwater is not allowed to drain away. In this case, the total melting is almost doubled compared with the well-drained situation. With increasing values of the initial water depth, the total ablation increases even further (Table 2; Fig. 6a and b). Up to an initial water depth of $50 \mathrm{~cm}$, the surface ablation increases rapidly, after which the effect is much reduced. The total ablation for the 30 day period is about two times greater compared with the bare-ice situation in 1999, and almost three times greater in 2001. This finding agrees very well with measurements on Arctic sea ice where the melt rate beneath melt ponds is quoted to be two to three times greater than for bare ice (Fetterer and Untersteiner, 1998). 

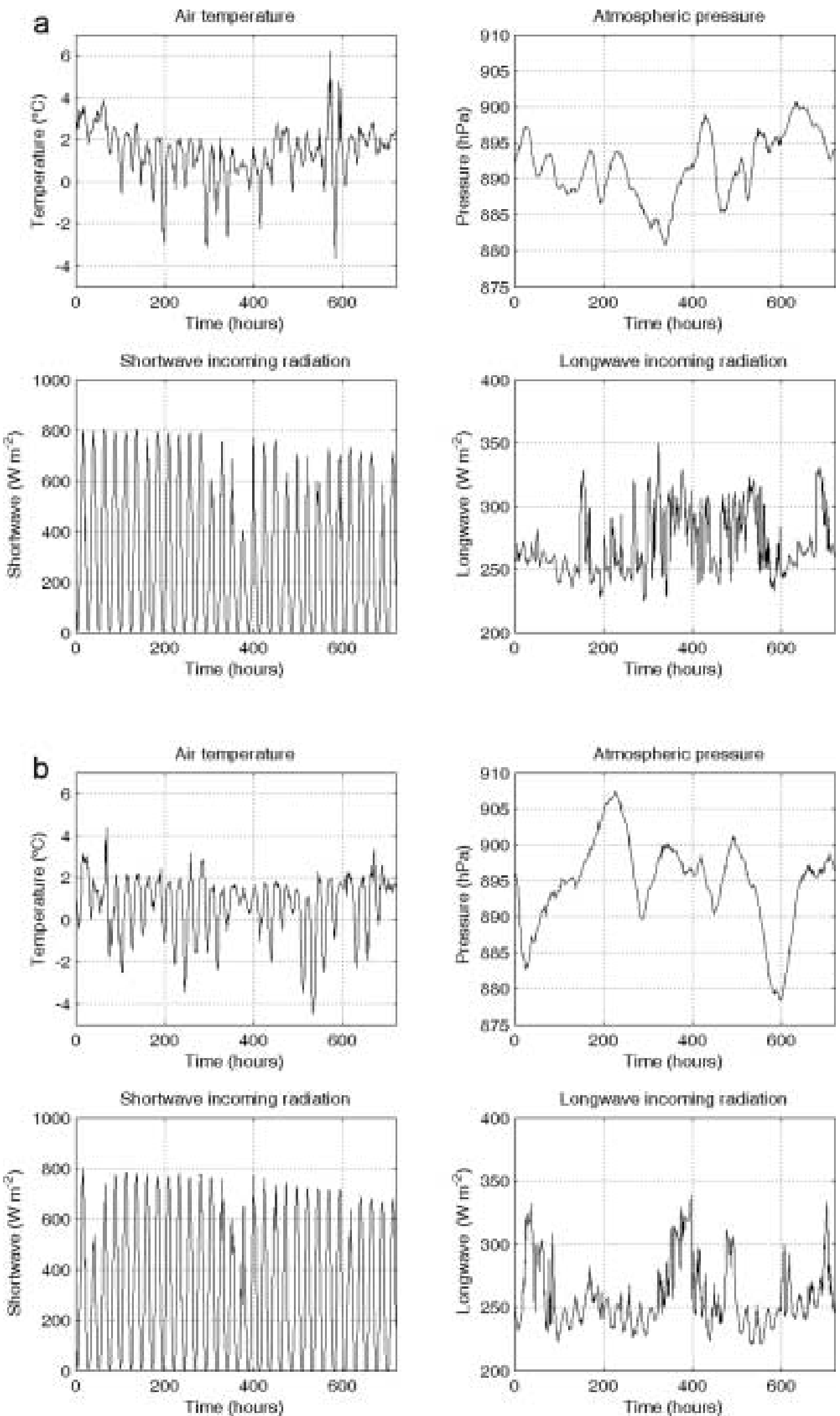

Fig. 4. Air temperature, atmospheric pressure, shortwave incoming radiation and longwave incoming radiation observed at $67^{\circ} 5^{\prime} \mathrm{N}$, $49^{\circ} 23^{\prime} \mathrm{W}$ at an elevation of $1000 \mathrm{~m}$, for a 30 day period beginning on 3 July (a) 1999 and (b) 2001. 

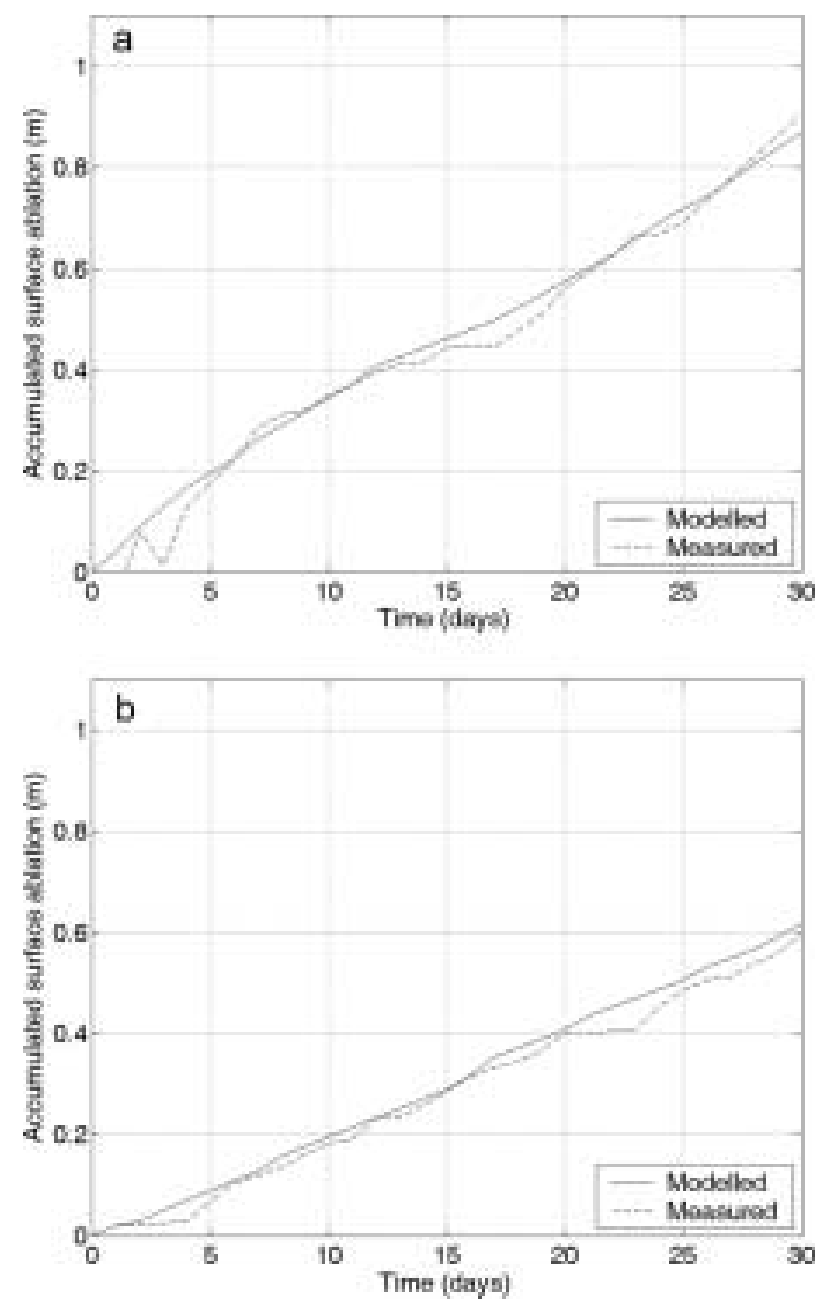

Fig. 5. Accumulated surface ablation observed (dashed line) and modelled (solid line) for a bare ice surface in (a) 1999 and (b) 2001 .

Table 3 shows for three different elevations the modelsimulated total surface ablation after 30 days of melting in 1999 and 2001 for an ice surface where meltwater is not allowed to drain away.

\subsection{Drainage model}

Figure 7 shows for the $20 \mathrm{~km} \times 20 \mathrm{~km}$ model area the calculated evolution of the percentage area covered by supraglacial lakes in 1999 and 2001. The area covered by supraglacial lakes peaked in 1999 at $7.7 \%$ and in 2001 at

Table 2. Accumulated ablation after 30 days of melting beneath a lake initialized with five different depths of water in 1999 and 2001

\begin{tabular}{lcc}
\hline Depth of water & 1999 & 2001 \\
$\mathrm{~cm}$ & $\mathrm{~cm}$ & $\mathrm{~cm}$ \\
\hline 0 & 161 & 125 \\
25 & 181 & 158 \\
50 & 187 & 167 \\
75 & 189 & 170 \\
100 & 190 & 171 \\
\hline
\end{tabular}
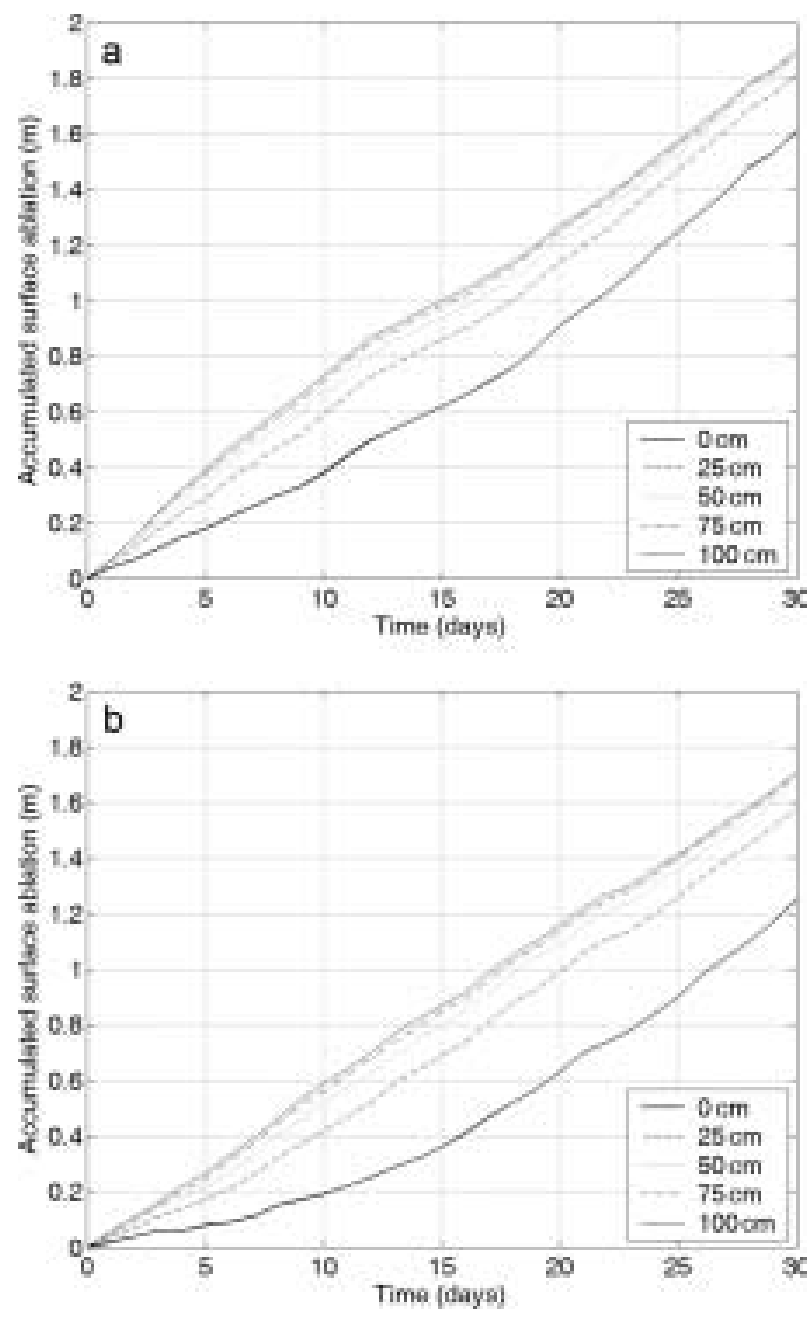

Fig. 6. Modelled accumulated surface ablation in (a) 1999 and (b) 2001 when water cannot drain, for five different initial water layer depths. The surface ablation increases up to an initial water layer depth of $50 \mathrm{~cm}$, after which the effect is much reduced.

$7.2 \%$ of the total area, reaching approximately constant values after 10-20 days. However, the process took longer in 2001 than in 1999. Figure 8a and b illustrate the modelled evolution in 2001 of the supraglacial lakes after 1 and 4 weeks of melting, respectively. After 1 week the lakes are not yet fully developed (Fig. 8a), but after 2 weeks only little change takes place. A comparison of the areas covered by the lakes after 4 weeks in 2001 and 1999 (Fig. 8b and c) shows only minor differences. The modelled maximum lake depths in 2001 and 1999 (10.16 and $10.28 \mathrm{~m}$ ) were also

Table 3. Accumulated ablation after 30 days of melting beneath a lake at three different elevations in 1999 and 2001. The model was initialized with $50 \mathrm{~cm}$ of water

\begin{tabular}{lcc}
\hline Elevation & 1999 & 2001 \\
$\mathrm{~m}$ & $\mathrm{~cm}$ & $\mathrm{~cm}$ \\
\hline 1000 & & \\
1200 & 187 & 167 \\
1400 & 151 & 130 \\
& 113 & 88
\end{tabular}




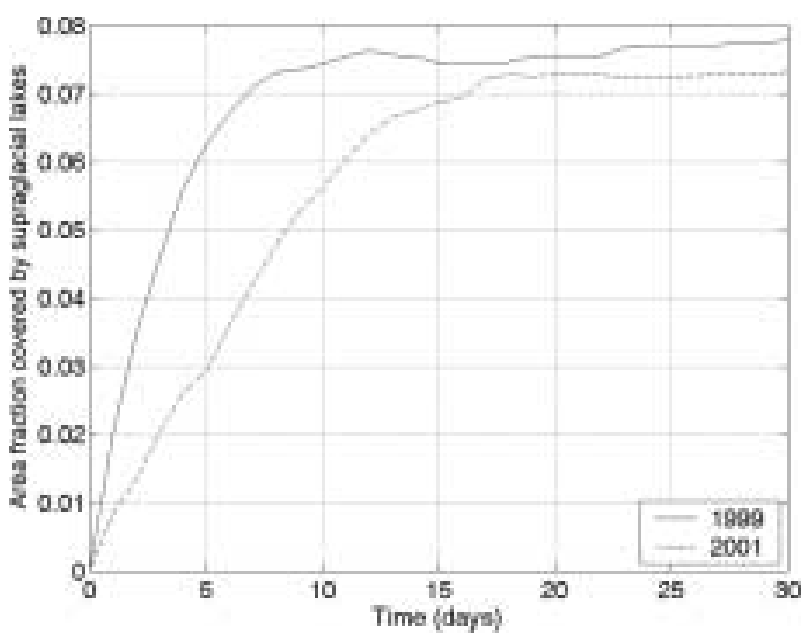

Fig. 7. Area fraction covered by supraglacial lakes, vs time, as modelled for 1999 (solid line) and 2001 (dashed line).

very similar. For comparison, Figure $8 d$ shows the location and magnitude of supraglacial lakes in the model area derived from analysis of a Landsat 7 image from 23 August 2000. There is good agreement between the modelled and observed positions of the lakes. However, the area covered by lakes in the Landsat 7 image is much less $(2.2 \%)$ than the lake areas calculated by the model (about 7\%). Comparing the location of the supraglacial lakes to a contour map of the area reveals that the lakes, as expected, form in depressions on the ice-sheet surface. The similarity of modelled area extent and lake depth in 1999 and 2001 in spite of the much greater total melt in 1999 indicates that the depressions in the ice surface fill up to a maximum water level, after which all added water drains away.

Figure 9 shows the area covered by supraglacial lakes vs time calculated for different values of the tuning parameter $\Omega$. The magnitude of $\Omega$ has a large influence on the modelled extent of the supraglacial lakes, particularly for low values of $\Omega$. The average surface gradient in the area investigated is around 0.009. Hence, according to Equation (18), the mean velocity of the meltwater flowing from high to low areas is $u=0.009 \Omega$. As mentioned in section 3, the meltwater drainage from the ice margin involves different processes with order-of-magnitude different flow speeds such as slow percolation through ice or snow, supraglacial run-off in small streams and big rivers and subglacial run-off via moulins. A reasonable assumption is that run-off is dominated by stream and river run-off with flow velocities that may reach several metres per second (Fig. 3). Even in lakes, the current can be strong. In a lake $600 \mathrm{~m}$ in length close to $67^{\circ} 09^{\prime} \mathrm{N}, 49^{\circ} 38^{\prime} \mathrm{W}$, for example, the central current was about $3 \mathrm{~m} \mathrm{~s}^{-1}$ (Maurette and others, 1986). This justifies our choice of $\Omega=u / 0.009$ equal to
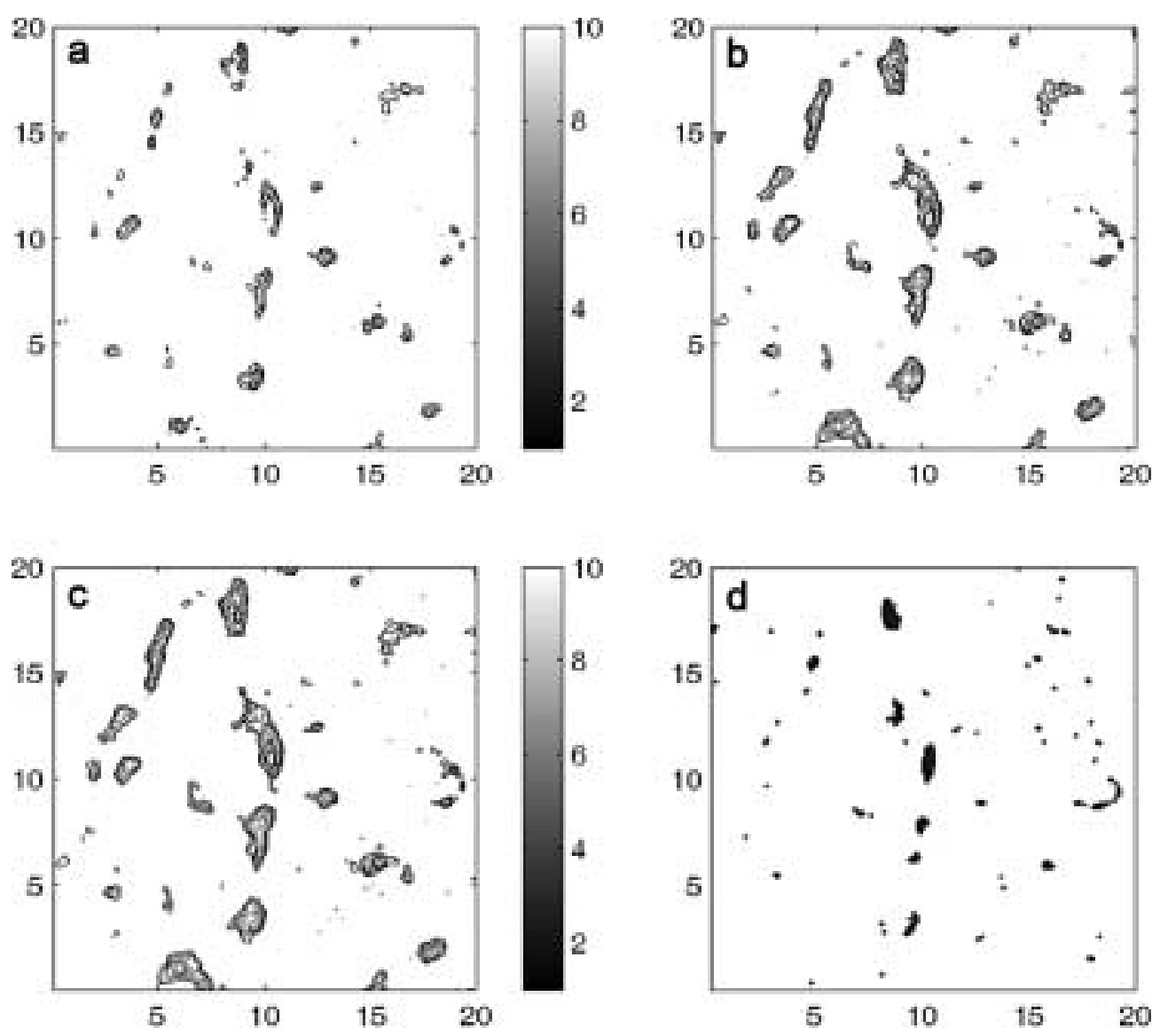

Fig. 8. (a, b) Area coverage and depth of supraglacial lakes as modelled in 2001 after (a) 1 week and (b) 4 weeks. The modelled area is $20 \mathrm{~km} \times 20 \mathrm{~km}$, located between $67^{\circ} 17^{\prime}$ and $67^{\circ} 28^{\prime} \mathrm{N}, 48^{\circ} 43^{\prime}$ and $49^{\circ} 11^{\prime} \mathrm{W}$. (c) The area covered by supraglacial lakes after 4 weeks in 1999. The maximum area covered was $7.7 \%$ in 1999 and $7.2 \%$ in 2001. Maximum depths were 10.28 and $10.16 \mathrm{~m}$ for the two years, respectively. (d) An analyzed Landsat 7 image from 23 August 2000 showing the location of the supraglacial lakes. The area covered by lakes constituted $2.2 \%$ of the surface area. 


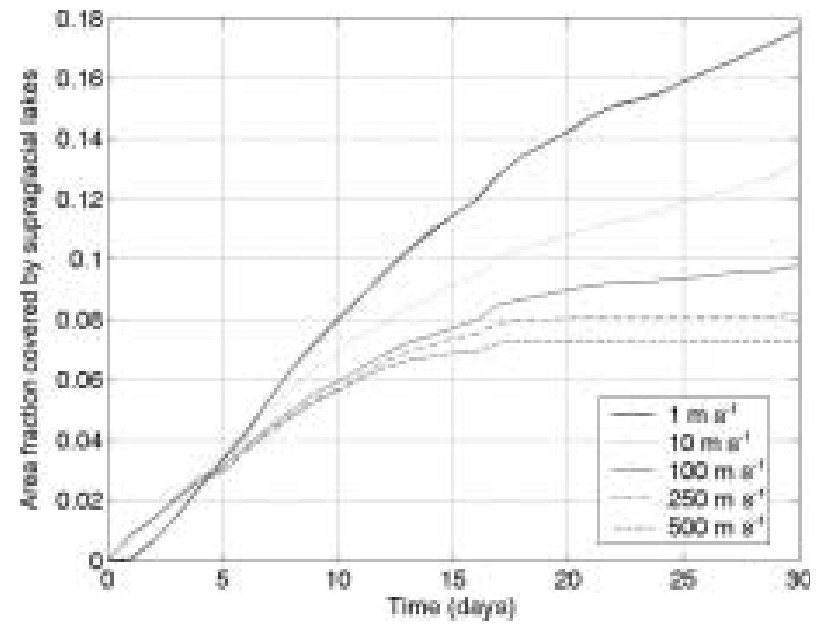

Fig. 9. Modelled area fraction covered by supraglacial lakes in 2001 for five different values of drainage parameter $\Omega$. When $\Omega>100 \mathrm{~m} \mathrm{~s}^{-1}$ the influence on the area fraction is limited.

$500 \mathrm{~m} \mathrm{~s}^{-1}$. However, as long as $\Omega$ is greater than $100 \mathrm{~m} \mathrm{~s}^{-1}$ the influence on the area extent of supraglacial lakes is limited (Fig. 9).

\subsection{Analysis of satellite images}

To investigate the large-scale area coverage of supraglacial lakes in Greenland, MODIS satellite images from the summers of 2000, 2001 and 2002 were analyzed. We used

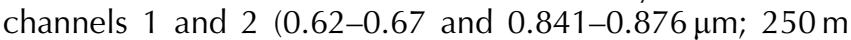
nadir resolution). Supraglacial lakes occur within much of the melt zone of the Greenland ice sheet, but are especially abundant on the western margin south of $70^{\circ} \mathrm{N}$. An area between $64^{\circ} 6^{\prime} \mathrm{N}$ and $71^{\circ} 12^{\prime} \mathrm{N}$ from the ice margin and well into the dry-snow zone was chosen for our investigation (Fig. 1b). The area was divided into four sub-areas. Cloudfree images for each of the four sub-areas from July 2000, 2001 and 2002 were geocoded and analyzed. The mean July coverage of supraglacial lakes for the total area was $0.69 \%$ in $2000,0.93 \%$ in 2001 and $0.87 \%$ in 2002 . In order to study to what extent these results were influenced by the $250 \mathrm{~m}$ nadir resolution of the MODIS sensor, one of the subareas was also analyzed using a Landsat 7 image from 23 August 2000 using the panchromatic channel (0.52$0.9 \mu \mathrm{m} ; 15 \mathrm{~m}$ nadir resolution). Only $6 \%$ difference in the area covered by supraglacial lakes was found. For the small area studied with the drainage model, analysis of the Landsat 7 image showed that supraglacial lakes actually covered only $2.2 \%$ of the area (Fig. $8 \mathrm{~d}$ ), i.e. much less than the approximately $7 \%$ obtained with the drainage model. One would expect the model-calculated area covered by lakes to be larger than the area observed in the Landsat 7 image, since this image was taken quite late in the melt season, when refreezing of the lake surfaces had begun (Fig. 10). However, it appears that the lakes in the model are formed at the same places as observed, but they are much larger and some of them are not even resolved as individual lakes. The explanation for the discrepancy is probably that the horizontal resolution of the DEM is not good enough to capture the drainage channels, and that vertical drainage through moulins is not included in the model.

Near the ice margin, a significant fraction of the meltwater drains through crevasses and moulins to the

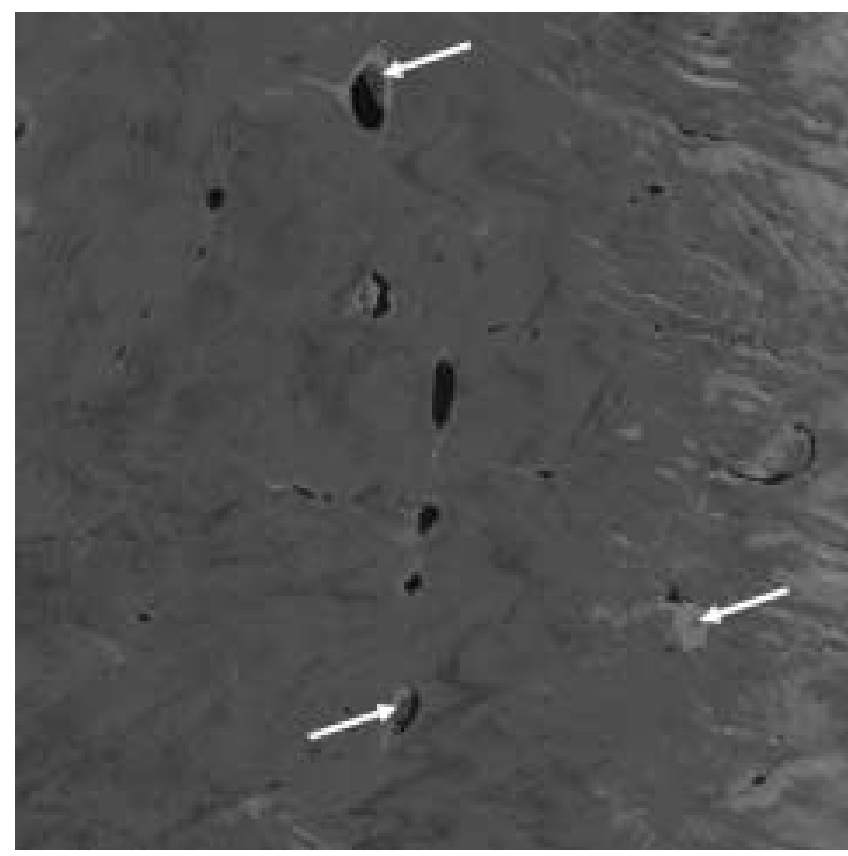

Fig. 10. Landsat 7 scene from 23 August 2000 showing the study area. The arrows indicate some of the locations where refreezing of supraglacial lake surfaces has started.

glacier bed (Zwally and others, 2002). In an area close to Swiss Camp on the West Greenland ice margin $\left(69.57^{\circ} \mathrm{N}\right.$, $49.31^{\circ} \mathrm{W}$ ) the area density of moulins is around $0.2 \mathrm{mou}$ lins $\mathrm{km}^{-2}$ (Thomsen and others, 1988; Zwally and others, 2002). To investigate the importance of moulins, the DEM was modified slightly by introducing drainage 'holes' acting as sinks placed randomly in depressions of the ice surface with an area density similar to that observed near Swiss Camp. This change reduced the maximum area covered by supraglacial lakes from $7.7 \%$ to $4.1 \%$ when the model was run with the 1999 data.

\section{CONCLUSION}

Using a one-dimensional high-resolution numerical model forced by observed climatic data, we simulated summer ablation for a bare ice surface in a 30 day period. The agreement with observed surface ablation in two different years (1999 and 2001) with highly different ablation rates was excellent. Next, we simulated the melt rate beneath a supraglacial lake, using a parameterization of albedo as a function of water depth based on observations from melt ponds on Arctic sea ice. The simulation also accounted for the convective heat transfer through the water layer. The surface ablation beneath the lake was enhanced by $110 \%$ in 1999 and by $170 \%$ in 2001 compared with the ablation for bare ice.

Using the calculated melt rates as input to a drainage model, we calculated the surface evolution of supraglacial lakes within a $400 \mathrm{~km}^{2}$ area of the West Greenland icesheet margin. Despite much higher melt rates in 1999 than in 2001, the lake area was only $7 \%$ larger in 1999 than in 2001. Compared with satellite-derived data, the modelcalculated area coverage of supraglacial lakes was three to four times too large. We suggest that this discrepancy is due to the fact that the resolution of the applied ice-surface DEM was too low and that vertical drainage through moulins was 
not accounted for in the model. The importance of moulins was tested by including randomly placed drainage holes in surface depressions acting as sinks. This nearly halved the area covered by supraglacial lakes.

Obviously supraglacial lakes are formed in depressions of the ice-sheet surface and, when a given water level is attained, further added meltwater will run off. Within the region where supraglacial lakes presently occur, a significant growth of the lake area in a warmer climate is therefore not to be expected unless the surface topography is changed dramatically. Furthermore, analysis of satellite images shows that less than $1 \%$ of the ablation region in southwest Greenland is presently covered by supraglacial lakes. Therefore, despite an enhanced melt rate of up to $170 \%$ beneath the lakes, the extra surface ablation caused by the supraglacial lakes within this area is minimal. However, in a warmer climate, surface melting will occur higher up on the ice sheet where small surface slopes will favour formation of large supraglacial lakes. Enhanced surface melting beneath such lakes is a hitherto overlooked feedback mechanism related to climate warming.

\section{ACKNOWLEDGEMENTS}

The elevation map was produced by J. Mohr using European Remote-sensing Satellite (ERS) data: ERS-1, 20 October 1995, orbit 22300; ERS-2, 21 October 1995, orbit 02627; ERS-1, 29 December 1995, orbit 23302; and ERS-2, 30 December 1995, orbit 03629. The fieldwork on the Greenland ice margin was performed by C. Lüthje and M. Lüthje, supported by the Arctic Technology Centre of the Technical University of Denmark (DTU), COWIfonden, the Geological Survery of Denmark and Greenland (GEUS), Hilleberg, Ketner Outdoor A/S and Fujifilm Denmark. The work on aerial classification of the MODIS images was carried out with help from N. Elmqvist and P. Ravn. We also thank P. Miller and P. Taylor for language revision and J. Walder, I. Joughin, C. Lüthje and two anonymous referees for thorough reviews that led to significant improvements in the paper.

\section{REFERENCES}

Ageta, Y. and 6 others. 2000. Expansion of glacier lakes in recent decades in the Bhutan Himalayas. IAHS Publ. 264 (Symposium at Seattle 2000 - Debris-Covered Glaciers), 165-175.

Ahlstrøm, A.P. 2003. Ice sheet ablation assessed by observation, modelling and remote sensing. (PhD thesis, University of Copenhagen.)

Alexiades, V. and A.D. Solomon. 1993. Mathematical modeling of melting and freezing processes. Washington, DC, Hemisphere Publishing Corp.

Benn, D.I., S. Wiseman, and C.R. Warren. 2000. Rapid growth of a supraglacial lake, Ngozumpa Glacier, Khumbu Himal, Nepal. IAHS Publ. 264 (Symposium at Seattle 2000 - Debris-Covered Glaciers), 177-185.

Box, J.E. 1997. Melt pond depth variations and albedo in the Jacobshavn ablation region of the Greenland ice sheet. [Abstract U21A-19.] EOS Trans. AGU, 78(46).

Ebert, E.E. and J.A. Curry. 1993. An intermediate one-dimensional thermodynamic sea ice model for investigating ice-atmosphere interactions. J. Geophys. Res., 98(C6), 10,085-10,109.

Echelmeyer, K., T.S. Clarke and W.D. Harrison. 1991. Surficial glaciology of Jakobshavns Isbræ, West Greenland: Part I. Surface morphology. J. Glaciol., 37(127), 368-382.
Fetterer, F. and N. Untersteiner. 1998. Observations of melt ponds on Arctic sea ice. J. Geophys. Res., 103(C11), 24,821-24,835.

Grenfell, T.C. 1979. The effects of ice thickness on the exchange of solar radiation over the polar oceans. J. Glaciol., 22(87), 305-320.

Grenfell, T.C. and D.K. Perovich. 1984. Spectral albedos of sea ice and incident solar irradiance in the southern Beaufort Sea. J. Geophys. Res., 89(C3), 3573-3580.

Grenfell, T.C. and G.A. Maykut. 1977. The optical properties of ice and snow in the Arctic Basin. J. Glaciol., 18(80), 445-463.

Greuell, W. and W.H. Knap. 2000. Remote sensing of the albedo and detection of the slush line on the Greenland ice sheet. J. Geophys. Res., 105(D12), 15,567-15,576.

Greuell, W., C.H. Reijmer and J. Oerlemans. 2002. Narrowbandto-broadband albedo conversion for glacier ice and snow based on aircraft and near-surface measurements. Remote Sens. Environ., 82(1), 48-64.

Hanesiak, J.M., D.G. Barber, R.A. De Abreu and J.J. Yackel. 2001. Local and regional albedo observations of Arctic firstyear sea ice during melt ponding. J. Geophys. Res., 106(C1), 1005-1016.

Huppert, H.E. 2000. Geological fluid mechanics. In Bachelor, G.K., H.K. Moffatt and M.G. Worster, eds. Perspectives in fluid dynamics: a collective introduction to current research. Cambridge, Cambridge University Press, 447-506.

Incropera, F.P. and D.P. DeWitt. 2002. Fundamentals of heat and mass transfer. Fifth edition. New York, etc., John Wiley and Sons.

Jezek, K.C., M.R. Drinkwater, J.P. Crawford, R. Bindschadler and R. Kwok. 1993. Analysis of synthetic aperture radar data collected over the southwestern Greenland ice sheet. J. Glaciol., 39(131), 119-132.

Konzelmann, T., R.S.W. Van de Wal, J.W. Greuell, R. Bintanja, E.A.C. Henneken and A. be-Ouchi. 1994. Parameterization of global and longwave incoming radiation for the Greenland ice sheet. Global Planet. Change, 9(1-2), 143-164.

Kraus, E.B. 1972. Atmosphere-ocean interaction. Oxford, Clarendon Press.

Liestøl, O., K. Repp and B. Wold. 1980. Supra-glacial lakes in Spitsbergen. Nor. Geogr. Tidsskr., 34(2), 89-92.

Linden, P.F. 2000. Convection in the environment. In Bachelor, G.K., H.K. Moffatt and M.G. Worster, eds. Perspectives in fluid mechanics. Cambridge, Cambridge University Press, 287-343.

Lüthje, M. 2005. Modelling drainage processes: a numerical and remote sensing investigation of pond formation on ice surfaces. (PhD thesis, Technical University of Denmark.)

Lüthje, M., D.L. Feltham, P.D. Taylor and M.G. Worster. 2006. Modeling the summertime evolution of sea-ice melt ponds. J. Geophys. Res., 111(C2), C02001. (10.1029/2004JC002818.)

Maurette, M., C. Hammer, D.E. Brownlee, N. Reeh and H.H. Thomsen. 1986. Placers of cosmic dust in the blue ice lakes of Greenland. Science, 233(4766), 869-872.

Morassutti, M.P. 1992. Component reflectance scheme for DMSPderived sea ice reflectances in the Arctic Basin. Int. J. Remote Sensing, 13(4), 647-662.

Morassutti, M.P. and E.F. LeDrew. 1996. Albedo and depth of melt ponds on sea ice. Int. J. Climatol., 16(7), 817-838.

Oerlemans, J. 1992. Climate sensitivity of glaciers in southern Norway: application of an energy-balance model to Nigardsbreen, Hellstugubreen and Alfotbreen. J. Glaciol., 38(129), 223-232.

Perovich, D.K. and W.B. Tucker, III. 1997. Arctic sea-ice conditions and the distribution of solar radiation during summer. Ann. Glaciol., 25, 445-450.

Perovich, D.K. and 8 others. 1999. SHEBA: snow and ice studies. Hanover, NH, US Army Corps of Engineers. Cold Regions Research and Engineering Laboratory. CD-ROM.

Perovich, D.K., W.B. Tucker, III and K.A. Ligett. 2002. Aerial observations of the evolution of ice surface conditions during summer. J. Geophys. Res., 107(C10), 8048. (10.1029/ 2000JC000449.) 
Reynolds, J.M. 2000. On the formation of supraglacial lakes on debris-covered glaciers. IAHS Publ. 264 (Symposium at Seattle 2000 - Debris-Covered Glaciers), 153-161.

Steffen, K. and J. Box. 2001. Surface climatology of the Greenland ice sheet: Greenland Climate Network 1995-1999. J. Geophys. Res., 106(D24), 33,951-33,964.

Taylor, P.D. and D.L. Feltham. 2004. A model of melt pond evolution on sea ice. J. Geophys. Res., 109(C12), C12007. (10.1029/2004JC002361.)

Thomsen, H.H. 1986. Photogrammetric and satellite mapping of the margin of the inland ice, West Greenland. Ann. Glaciol., 8, 164-167.

Thomsen, H.H. and N. Reeh. 1986. Glaciological investigations at the margin of the Inland Ice north-east of Jakobshavn, West Greenland. Grønl. Geol. Unders. Rapp. 130, 102-108.
Thomsen, H.H., L. Thorning and R.J. Braithwaite. 1988. Glacierhydrological conditions on the Inland Ice north-east of Jacobshavn/Ilulissat, West Greenland. Grønl. Geol. Unders. Rapp. 138.

Van de Wal, R.S.W. and J. Oerlemans. 1994. An energy balance model for the Greenland ice sheet. Global Planet. Change, 9(1-2), 115-131.

Zuo, Z. and J. Oerlemans. 1996. Modelling albedo and specific balance of the Greenland ice sheet: calculations for the Søndre Strømfjord transect. J. Glaciol., 42(141), 305-317.

Zwally, H.J., W. Abdalati, T. Herring, K. Larson, J. Saba and K. Steffen. 2002. Surface melt-induced acceleration of Greenland ice-sheet flow. Science, 297(5579), 218-222.

MS received 29 January 2005 and accepted in revised form 6 August 2006 